\title{
Partisipasi Tokoh Masyarakat Dalam Memberikan Pendidikan Seks pada Anak
}

\section{Syamsuddin}

\author{
Nurdin \\ Universitas Muhammadiyah Makassar \\ nurdin@unismuh.ac.id
}

\author{
Hambali \\ Universitas Muhammadiyah Makassar \\ hambali@unismuh.ac.id
}

\begin{abstract}
ABSTRAK
Tujuan penelitian ini adalah untuk mengetahui partisipasi tokoh masyarakat dalam memberikan pendidikan seks pada anak agar para remaja tidak terjerumus dalam seks bebas.Adapun subyek dalam penelitian ini yaitu 3 orang remaja, 3 orang tua para remaja, 3 masyarakat. Pendekatan yang digunakan dalampenelitian ini adalah penelitian kualitatif dekriptif yaitu suatu prosedur penelitian yangmenghasilkan kata-kata tertulis atau lisan dari orang-orang dan perilaku yangdiamati selama melakukan penelitian ini,.Dasar penelitian yang digunakanadalah studi kasus, dimana penelitian yang dilakukan secara intensif,terperinci dan mendalam terhadap objek penelitan guna menjawabpermasalahan dari peneliti. Sedangkan tipe penelitian adalah Purposive Sampling merupakan pemilihan siapa subjek yang ada dalam posisi terbaik untuk memberikan informasi yang dibutuhkan tentang partisipasi tokoh masyarakat dalam memberikan pendidikan seks pada anak di kelurahan Lette kota Makassar.Hasil penelitian ini menunjukkan bahwa partisipasi tokoh masyarakat terhadap remaja yang baik dan benar dalam meminimalisir tindakan penyimpangan seks bebas dalam kehidupan remaja yaitu d butuhkan peran orang tua serta partisipasi tokoh masyarakat dalam memerangi seks bebas dalam kehidupan remaja.Remaja dapat mematuhi aturan dalam keluarga, masyarakat dan memilih teman bergaul agar terhindar dalam pergaulan bebas .Dengan adanya partisipasi tokoh masyarakat yang baik dan benar remaja dapat terhindar dari seks bebas.
\end{abstract}

Kata Kunci : Sosialisasi, Remaja, Seks Bebas.

\section{PENDAHULUAN}

Pendidikan seksadalah suatu informasi mengenai persoalan seksualitas manusia yang jelas dan benar, yang meliputi proses terjadinya pembuahan, kehamilan sampai kelahiran, tingkah laku seksual, hubungan seksual, dan aspek-aspek kesehatan, kejiwaan dan kemasyarakatan. Masalah pendidikan seksual yang diberikan sepatutnya berkaitan dengan norma-norma yang berlaku di masyarakat, apa yang dilarang, apa yang dilazimkan dan bagaimana melakukannya tanpa melanggar aturan-aturan yang berlaku di masyarakat (Sarlito, 1994). Pendidikan seksual merupakan cara pengajaran atau pendidikan yang dapat menolong remaja untuk mengatasi masalah yang bersumber pada dorongan seksual. Dengan demikian pendidikan seksual ini bertujuan umtuk menerangkan segala hal yang berhubungan dengan seks dan seksualitas dalam bentuk 
yang wajar.Dalam hal ini sebaiknya pendidikan seksual diberikan pertama kali oleh orang tua, tetapi tidak semua orang tua mau terbuka terhadap anak dalam membicarakan masalah seksual.Tingkat sosial ekonomi maupun tingkat pendidikan yang berbeda menyebabkan ada orang tua yang mau dan mampu memberikan penerangan tentang seks tetapi lebih banyak yang tidak mampu dan memahami permasalahan tersebut (Gunarsa, 1991).Pendidikan seks di Indonesia masih menjadi kontroversi, masih banyak anggota masyarakat yang belum menyetujui pendidikan seks di rumah maupun di sekolah. Dampaknya bisa kemana-mana, antara lain dalam memilih tontonan yang berbudaya barat yang digambarkan dalam film ataupun video sering kali menunjukan kehidupan seks bebas di kalangan remaja, itu bukan semata-mata karena ketagihan tetapi timbul karena adanya persepsi bahwa melakukan hubungan seksual sudah merupakan hal yang biasa. Sebab itu pendidikan seks hendaknya menjadi bagian penting dalam pendidikan di sekolah ke tidaktahuan remaja mengenai seks dapat dilihat dari penelitian yang dilakukan "synovate" sebuah perusahaan yang bergerak di bidang jasa dan pemasaran pada tahun 2004 terhadap 450 remaja dari Jakarta, Bandung, Surabaya dan Medan yang membuktikan remaja tidak mempunyai pengetahuan khusus serta komprehensif mengenai seks. Informasi utama mereka, didapat dari teman 65 persen, film porno 35 persen, sekolah 19 persen dan orang tua 5 persen (BKKBN, 2004). Menjawab persoalan di atas, sekiranya perlu pendidikan seks bagi remaja. Namun pelaksanaannya sampai sekarang terkendala karena pengaruh budaya masyarakat Indonesia yang masih menganggap seks itu adalah hal alamiah yang akan diketahui dengan sendirinya setelah remaja menikah sehingga dianggap tabu untuk dibicarakan secara terbuka ( Mu'tadin, 2002 ). Sikap mentabukan dan tidak terbuka mengenai seks ini menurut Suarta (2002) malah akan memancing rasa penasaran remaja yang berakhir pada perilaku seksual yang tidak sehat dan merugikan kesehatan reproduksi remaja.

Perbedaan dalam menyikapi seks tersebutlah yang mengakibatkan sampai sekarang masih terjadi pro-kontra terhadap perlu tidaknya memberikan pendidikan seks bagi remaja. Kelompok yang menolak beranggapan bahwa pendidikan seks akan menjerumuskan para remaja untuk melakukan hubungan seksual sebelum menikah sementara kelompok yang mendukung beranggapan bahwa pendidikan seks bisa mencegah remaja melakukan hubungan seks sebelum menikah karena telah mengetahui resiko-resiko yang akan dihadapinya ( Lukman, 2004 ). 


\section{LANDASAN TEORI}

Menurut Nurhayati (2007), tanggung jawab orang tua tidak hanya mencakup atau terbatasi pada kebutuhan materi saja, tetapi sesungguhnya mencakup juga kepada seluruh aspek kehidupan anaknya, termasuk di dalamnya aspek pendidikan seksual. Di mana pemahaman dan pemilihan metode pendidikan seksual yang tepat akan mengantarkan anak menjadi insan yang dapat menjaga dirinya dari perbuatan-perbuatan yang terlarang dan sadar akan ancaman dan peringatan dari perbuatan zina serta memiliki pegangan agama yang jelas.Keluarga, orang tua dan tokoh masyarakat adalah madrasah pertama dan utama bagi anak. Karena di sanalah mereka mulai belajar dan mengetahui segala sesuatu, termasuk seks. Di samping itu, orang tua ádalah pihak pertama yang bertanggung jawab dalam membina dan mendidik serta memonitor perkembangan baik fisik, emosional, maupun seksual putra-putrinya.Pendidikan seks perlu diberikan kepada setiap orang, termasuk remaja. Sebagaimana halnya pendidikan intelektual, kecakapan, kesenian dan sebagainya. Jika anak perlu diberikan pendidikan intelektual dengan dasar anak memiliki akal pikiran, maka pendidikan sekspun diberikan karena manusia memiliki potensi biologis.

\section{METODE PENELITIAN}

Penelitian ini adalah penelitian sosial budaya dengan pendekatan Kualitatif.Penelitian kualitatif adalah penelitian tentang riset yang bersifat deskriptif dan cenderung menggunakan analisis. Proses dan makna (perspektif subyek) lebih ditonjolkan dalam penelitian kualitatif. Landasan teori dimanfaatkan sebagai pemandu agar fokus penelitian sesuai dengan fakta di lapangan. Selain itu landasan teori juga bermanfaat untuk memberikan gambaran umum tentang latar penelitian dan sebagai bahan pembahasan hasil penelitian.Dalam penelitian kualitatif peneliti bertolak dari data, memanfaatkan teori yang ada sebagai bahan penjelas, dan berakhir dengan suatu "teori". Adapun tipe penelitian, Purposive Sampling merupakan pemilihan siapa subjek yang ada dalam posisi terbaik untuk memberikan informasi yang dibutuhkan. Karena itu, menentukan subjek atau orang-orAng terpilih harus sesuai dengan cirri-ciri khusus yang dimiliki oleh sampel tersebut.

\section{PEMBAHASAN}

Pendidikan seksual merupakan cara pengajaran atau pendidikan yang dapat menolong remaja untuk mengatasi masalah yang bersumber pada dorongan seksual. 
Dengan demikian pendidikan seksual ini bertujuan umtuk menerangkan segala hal yang berhubungan dengan seks dan seksualitas dalam bentuk yang wajar. Dalam hal ini sebaiknya pendidikan seksual diberikan pertama kali oleh orang tua, tetapi tidak semua orang tua mau terbuka terhadap anak dalam membicarakan masalah seksual,sifat ketidakterbukaan inilah sehingga remaja terjerumus dalam pergaulan seks bebas,menkomsumsi obat-abatan terlarang,minum-minuman keras dan masih banyak lagi yang di lakukan oleh remaja untuk bisa d katakan gaul dalam teman sebayahnya tanpa memikirkan bahaya yang di timbulkan dan bukan orang tua saja yang berperan dalam memberikan pendidikan seks pada remaja tetapi tokoh masyarakat juga.Adapun teori yang bersangkutan adalah teori penyimpangan.Perilaku menyimpang adalah setiap perilaku yang tidak sesuai dengan nilai-nilai dan tata aturan atau norma-norma yang berlaku dalam masyarakat. Secara sederhana kita memang dapat mengatakan, bahwa seseorang berperilaku menyimpang apabila menurut anggapan sebagian besar masyarakat (minimal disuatu kelompok atau komunitas tertentu) perilaku atau tindakan tersebut di luar kebiasaan, adat istiadat, aturan, nilai-nilai atau norma sosial yang brlaku. Misalnya, suka minum-minuman keras atau terlibat narkotika disebut juga sebagai penyimpangan tunggal atau bila seseorang mengembangkan berbagai perilaku yang melanggar sejumlah aturan atau norma sosial yang berlaku. sedangkan penyimpangan jamak yaitu selain berprofesi sebagai pencuri atau perampok, mereka acapkali juga seorang alkoholik, gemar melacur dan suka menggunakan tindakan kekerasan.Menurut Bruce J. Cohen dalam bukunya Idianto Muin( 2013:156), perilaku menyimpang adalah setiap perilaku yang tidak berhasil menyesuaikan diri dengan kehendak-kehendak masyarakat atau kelompok tertentu dalam masyarakat. Menurut Paul B. Horton penyimpangan adalah setiap perilaku yang dinyatakan sebagai pelanggaran terhadap norma-norma kelompok atau masyarakat.Perilaku menyimpang adalah perilaku manusia yang bertentangan atau tidak sesuai dengan nilai-nilai atau norma-norma yang berlaku dalam masyarakat.Masa perkembangan anak merupakan masa transmisi dari anak menjadi dewasa.Oleh sebab itu membutuhkan bimbingan penuh dari kedua orang tuanya. Gambaran umumnya merupakan suatu periode yang dimulai dengan perkembangan masa pubertas dan menyelesaikan pendidikan untuk tingkat menengah, dimana perubahan biologis yang membawanya pada usia belasan seringkali mempengaruhi perilaku anak dalam perkembangannya. 


\section{Partisipasi Tokoh Masyarakat dalam Memberikan Pendidikan Seks}

Partisipasi adalah keterlibatan masyarakat dalam proses perencanaan dan pembuatan keputusan tentang apa yang di lakukan dalam pelaksaan program dan pengambilan keputusan untuk berkontribusi sumber daya atau kerja sama dalam organisasi atau gegiatan khusus, berbagai manfaat dari program pembagunan dan evaluasi program pembagunan.Partispasi tokoh masyarakat terlebih dahulu kita ketahui apa itu masyarakat,masyarakat adalah sekolompak manusia yang terdiri dari beberapa orang selanjutnya tokoh adalah orang yang sangat berperan d suatu masyarakat untuk merubah yang lebih baik.Seperti pendidikan seks pada anak di mana banyaknya para remaja yang terjerumus dalam pergaulan bebas tanpa memikirkan masa depannya kedepan namun hal itu kembalikan ke orang tua masing-masing karna orang tualah yang sangat berperan dalam memberikan pendidikan seks pada anaknya agar tidak terjerumus dalam pergaulan seks bebas,namun pendidikan seks ini masih pro dan kontrak dalam masyarakat. Tokoh masyarakat hanya bisa memberikan pemahaman kepada orang tua tentang pendidikan seks agar anak mereka tidak terjerumus dalam seks bebas,seperti yang kita ketahui remeja itu rasa ingin tahunya sangat tinggi sehingga butuh arahan atau petunjuk dari orang tuanya serta masyarakat pada umumnya agar para remaja kita tidak salah dalam bergaul tapi biasanya orang tua remaja malu untuk memberikan pendidikan seks pada anaknya pada hal pendidikan seks itu sangat penting dan remaja juga kalau kurang di perhatikan sama orang tuanya inilah yang biasa mengakibatkan remaja ini terjerumus hal yang tidak di inginkan seperti menkomsumsi obat-obat terlarang,menperkosa,melakukan seks bebas hal inilah yang harus di jaga bersama agar tidak terjadi dalam lingkungan kita dan masyarakat juga berperan penting dalam memberikan pendidikan seks kepada para remaja,apa bila ada remaja yang datang kerumah anda berikanlah pemahaman tentang pendidikan seks agar para remaja kita tertolong dalam seks bebas,apa lagi kita ketahui saat ini banyaknya remaja yang melakukan seks bebas karna kurangnya pendidikan seks dari orang tuanya serta dari tokoh masyarakat.

\section{Pendidikan seks pada anak}

Karakter positif tidak terbentuk dengan sendirinya, melainkan pada suatu upaya tertentu dari orang-orang disekitarnya (keluarga, guru, teman bergaul) untuk dapat tumbuh berkembang seperti yang diharapkan, sosialisasi yang sangat berpengaruh adalah lingkungan keluarga. Orangtua membimbing anaknya dalam penanaman nilai-nilai yang baik, dapat menjaga nama baik keluarganya. Sebagai orangtua perluh mengarahkan anak kemana dia harus pergi, dengan siapa diaharus bergaul, bagaimana dia harus 
bertindak,hidup seperti apa yang baik. Orangtua harus menjadi tempat curhat dan penuh kasih sayang terhadap anaknya. Melihat kondisi sikap dan perilaku remaja masa kini sangat memperihatinkan seperti melekukan seks bebas, menperkosa,minum obat-obat terlarang gaya hidup kebarat-baratan dalam hal ini pergaulan bebas. oleh karena itu penanaman nilai moral terhadap remaja sangatlah penting dalam lingkungan keluaraga karena tempat yang pertama seorang anak memperoleh pendidikan adalah orang tua dan masyarakat. Mendidik anak dengan cara ditekan akan mengakibatkan anak itu jadi nakal, mungkin saja dalam lingkungan keluarga anak tidak menunjukkan perilaku-perilaku yang tidak baik tapi dilingkungan luar bisa jadi anak melakukan hal-hal yang melanggar aturan yang ada, begitupun dengan anak yang berasal dari keluarga yang broken home. Jika seorang remaja dalam lingkungan keluarga merasa tidak nyaman kemunkinan besar akan terjerumus dalam pergaulan bebas karena lebih banyak menghabiskan waktu diluar rumah, ketika bergaul sama orang salah dan ikut-ikutan maka hancur pulalah remaja tersebut, bergitupunn dengan sekolahnya menurunnya prestasi, masa depan remaja akan hancur.

Pergaulan bebas juga disebabkan juga sosialisasi media massa yang salah karena masa remaja adalah masa peralihan masa kanak-kanak ke masa dewasa, anak remaja masih labil belum mampu mempilter mana yang baik mana yang buruk. Media massa jika di manfaatkan dengan baik maka akan baik juga hasilnya tetapi jika disalahgunakan maka akan patal jadinya. karena seks bebas menyebabkan hamil di luar nikah dan salah satu solusinya adalah aborsi. Tidak ingin diketahui oleh orangtua, dan masyarakat banyak.Sebagai jalan pintas melakukan tindakan penyimpangan seks bebas.Pendidikan seksual merupakan cara pengajaran atau pendidikan yang dapat menolong remaja untuk mengatasi masalah yang bersumber pada dorongan seksual. Dengan demikian pendidikan seksual ini bertujuan umtuk menerangkan segala hal yang berhubungan dengan seks dan seksualitas dalam bentuk yang wajar.Dalam hal ini sebaiknya pendidikan seksual diberikan pertama kali oleh orang tua, tetapi tidak semua orang tua mau terbuka terhadap anak dalam membicarakan masalah seksual.Tingkat sosial ekonomi maupun tingkat pendidikan yang berbeda menyebabkan ada orang tua yang mau dan mampu memberikan penerangan tentang seks tetapi lebih banyak yang tidak mampu dan memahami permasalahan tersebut jadi di sinilah d butuhkan partisipasi seorang tokoh masyarakat agar seorang remaja tidak terjerumus dalam seks bebas terlebih orang tua remaja dalam memberikan pendidikan seks pada anaknya.Pendidikan seksual yang baik harus dilengkapi dengan pendidikan etika, pendidikan tentang hubungan antar sesama manusia 
baik dalam hubungan keluarga maupun di masyarakat. Karna remaja itu rasa ingin tahunya tinggi sehingga orang tua sangat berperan penting didalam keluarganya dan tujuan dari pendidikan seksual bukan untuk menimbulkan rasa ingin tahu dan rasa ingin mencoba hubungan seksual antar remaja, tetapi ingin menyiapkan agar remaja tahu tentang seksualitas dan akibat-akibatnya bila dilakukan tanpa mematuhi aturan hukum, agama dan adat istiadat serta kesiapan mental dan material seseorang dan tokoh masyarakat juga berperan penting dalam memberikan pehaman tentang seks agar para remaja tidak terjerumus dalam sesk bebas.

\section{KESIMPULAN}

Pendidikan seksual merupakan cara pengajaran atau pendidikan yang dapat menolong remaja untuk mengatasi masalah yang bersumber pada dorongan seksual. Dengan demikian pendidikan seksual ini bertujuan umtuk menerangkan segala hal yang berhubungan dengan seks dan seksualitas dalam bentuk yang wajar.Dalam hal ini sebaiknya pendidikan seksual diberikan pertama kali oleh orang tua, tetapi tidak semua orang tua mau terbuka terhadap anak dalam membicarakan masalah seksual.Berdasarkan hasil penelitian yang telah disajikan dalam pembahasan pada bab terdahulu, fenomena tentang seks bebas telah marak diperbincangkan dikalangan masyarakat, bukan hanya dari kalangan atas saja, tetapi bahkan dikalangan bawah pun sudah terjadi hal semaca seks bebas. Tujuan dari hasil penelitian ini adalah untuk mengetahui tentang partisipasi tokoh masyarakat dalam memberikan pendidikan seks pada anak di kelurahan Lette kecamatan Mariso kota Makassar, dan pentingnya pendidikan seks pada anak di kelurahan Lette Kecamatan Mariso di Kota Makassar.

\section{DAFTAR PUSTAKA}

Idrus Muhammad. (2009). Metode Penelitian Ilmu Sosial. Yogyakarta: Penerbit Erlangga.

J. Dwi Narwoko \& Bagong Suyanto. (2011). Sosiologi Teks Pengantar Dan Terapan. Jakarta: Kencana.

Lyen, A. (1976). Individu dan Masyarakat. Bandung: Sumur Bandung

Moleong. (2006). Metode Penelitian Kualitatif. Bandung : PT. Remaja Rosdakarya

Sarwono, Sarlito W. (2013). Psikologi Remaja.Jakarta: Rajawali Pers.

Shadily, Hasan. (1993). Sosiologi Untuk Masyarakat Indonesia. Jakarta : Rineka Cipta. 
Soekanto Soerjono (2012). Sosiolgi suatu pengantar: Jakarta.PT Raja Grafindo Persada.

Sugiono, (2008), Metodologi penelitian Kuantitatif, kualitatif, dan R\&D, Alfabeta, bandung.iop

Sutopo, HB, (2002) Metode penelitian kualitatif, PT. Remaja Rosda karya, Bandung,

Ulber Silalahi, Ma. (2012). Metode Penelitian Sosial. Bandung: PT Refika Aditama 